\title{
A COMPARATIVE STUDY ON THE MOTIVATION AND ATTITUDES OF LANGUAGE LEARNERS OF ONLINE DISTANCE AND TRADITIONAL IN-CLASSROOM EDUCATION
}

\author{
Dr. Gulten GENC \\ School of Foreign Languages \\ Inonu University, Malatya, TURKEY \\ Emine KULUSAKLI \\ School of Foreign Languages \\ Inonu University, Malatya, TURKEY \\ Savas AYDIN \\ School of Foreign Languages \\ Inonu University, Malatya, TURKEY
}

\section{ABSTRACT}

In recent years, the increase in the use of computer and the internet has led to a change in the traditional concept of formal education today. Distance learning as a more studentcentered system has been frequently used at universities. In this context, education has been applied to the individuals consisting of all age groups in accordance with their aspirations, expectations and interest in a more flexible way. This study aims to determine and compare the motivation and attitudes of language learners of online distance and traditional in-classroom education, in a state university in Turkey. Participants were $\mathbf{5 0 0}$ undergraduate university students in various disciplines. About $\mathbf{2 5 0}$ (half) of the participants studied English as a foreign language through traditional in-classroom education whereas the rest of the participants (250) studied English through online distance education in the same university by the same instructors. Two questionnaires (one to evaluate motivation level and one to evaluate attitudes of the participants related to English as a foreign language) and a background information form investigating individual information of the participants were used to collect data from the students of nine faculties at the University (including Faculty of Dentistry, Faculty of Pharmacy, Faculty of Education, Faculty of Arts and Sciences, Faculty of Fine Arts and Design, Faculty of Law, Faculty of Economics and Administrative Sciences, Faculty of Engineering, and Faculty of Medicine). According to the nature of the research, the study used descriptive statistics (frequencies, range, means, and standard deviations), t-test and ANOVA as the statistical analysis methods. All collected data were coded and computerized using the SPSS software and the alpha level for the tests was set at $\mathbf{0 5}$. After calculating each participant's motivation and attitudes scores, their scores were compared to the variables selected for the study and each other. The findings indicated statistically significant relationships between motivation and attitudes of the participants and some individual variables. Some conclusions were reached based on the findings of the research and some recommendations and suggestions were made for future research into areas not covered by this study.

Key Words: Motivation, attitude, language learning, distance education. 


\section{INTRODUCTION}

Technology offers many innovative features that can be used in language education. Distance education has been used over 100 years although the term is popular and new recently. As the primary means of distance learning; correspondence courses were the earlier forms of distance learning which started in Europe. Later, instructional radio and television became more popular and videotaped lectures have followed them. Videotaped lectures have been a standard in university and professional courses for the last two decades. Audiotapes and lessons sent through the mail have also been used in correspondence courses to teach subjects such as foreign language (Imel, 1998; Moore and Lockee, 1998; Teaster and Blieszner, 1999). Today, the Internet and compressed video have taken distance learning in new directions, allowing distance learning to occur in real time.

The term "distance education" has been used to describe the process of providing education where the instructor is distant (geographically separated) from the student (Gallagher and McCormick, 1999), or any instructional arrangement in which the teacher and learner are geographically separated to an extent that requires communication through media such as print or some other form of technology (Moore and Thompson, 1997, as cited in Spooner, Jordan, Algozzine, and Spooner, 1999; Perraton, 1988; Keegan, 1986; Garrison and Shale, 1987, as cited in Sherry, 1996). Greenberg (1998) defines distance learning as "a planned teaching/learning experience that uses a wide spectrum of technologies to reach learners at a distance and is designed to encourage learner interaction and certification of learning" (p. 36). Keegan (1995) states that distance education and training result from the technological separation of teacher and learner which frees the student from the necessity of travelling to "a fixed place, at a fixed time, to meet a fixed person, in order to be trained". The benefits and drawbacks of distance education have been revealed and studied by various researchers (Wheatley and Greer,1995; Bisciglia and Monk-Turner, 2002). They suggest that distance education provides the learners to save travel time since students and instructors do not have to travel to and from a home campus. Another benefit suggested by them was that students can work on the class according to their own schedules. There are also some drawbacks of distance education mentioned in the previous literature. Baker (1986) thinks that students might have some problems understanding technical, quantitative or scientifically oriented course information. Kahl and Cropley (1983) assert that unlike the traditional classroom, distance education does not allow instructors to modify lecture plans on the basis of moment-to-moment feedback from learners and this can affect the experiences of a student about the distance learning.

\section{Motivation of Language Learners}

Gardner's (1985) social psychological theory of L2 motivation has been used extensively to explore the structure of individual students' motivation, and links between students' existing quantity of motivation and their achievement in the L2. The theory comprises the construct of "integrative motivation", a model of second language acquisition derived from it, and a matching battery of psychometric tests designed to measure a variety of motivational factors (the Attitude/Motivation Test Battery, or AMTB). Motivation in language learning is the "desire to initiate second language learning and the effort employed to sustain it" (Ortega, 2009, p. 168; VanPatten and Benati, 2010). According to Dornyei (1990), there are two basic assumptions underlying the research as motivation in foreign language learning contexts is different in some ways from motivation in second language acquisition contexts and language learning is a series of diverse learning behaviours rather than a uniform process, which is often treated as for simplicity's sake.

Klesius, Homan and Thompson (1997) put forward that distance education is more likely to be perceived positively when students need the course content, enjoy little or no travel to the instruction site, and are intrinsically motivated. Intrinsic motivation is found to be a significant predictor of persistence and achievement in distance education (Coussement, 1995; Fjortoft, 1996). The novelty effect of the use of a new technology such as e-learning 
systems can help create curiosity and increase motivation to learn (Egan and Gibb, 1997). Motivated by the curiosity and demand for knowledge rather than by external reinforcements, learners are more likely to become involved in distance education more deeply and thus experience and enjoy the knowledge acquisition processes to a greater extent (Klesius et al.; Hardy and Boaz, 1997). In another study (Rovai, et al. 2007), multivariate analysis of variance is used to determine if there are differences in seven measures of motivation between students enrolled in 12 e-learning and 12 traditional classroom university courses. Study results provide evidence that e-learning students possess stronger intrinsic motivation than on campus students who attend face-to-face classes on three intrinsic motivation measures such as knowing, accomplishing things, experiencing stimulation. Additionally, Hiltz (1994) supports that distance learning students may have more motivation to achieve than traditional students.

However, Hurd (2005) considers that maintaining motivation levels is a challenge at distance learning. The demands of self-instruction with the shift of control from teacher to learner can be overwhelming for many students. Some students may have difficulty in coping with the amount and range of material at the start and for others, perceived inadequacy of feedback, frustration at unresolved problems, and lack of opportunities to practise with others and share experiences may have an adverse effect on motivation levels.

There are no differences in either three extrinsic motivation measures or amotivation. Allen, Mabry, Mattrey, Bourhis, Titsworth, and Burrell, (2004) stated that there is evidence indicating that technologies involved in distance learning have active effects on the learning process. Besides perceptions of the technologies themselves, various human factors such as personality, attitudes, and skill emerge to influence user reactions to communication technologies used in distance education. They also emphasize that given the extra effort perceived to be required for distance learning (mastering the technology of the course), the achievement scores of distance learning students may be the product of higher levels of motivation than traditional co-present students. The self-selection issue may represent a fundamental threat to the comparison found in the investigations. If distance learning students can be considered non-traditional (sometimes older) compared to face to face students, differential motivation may function as a form of biased sampling when the participant pools are drawn from groups with different reasons and motivations to participate in the particular instructional format.

\section{Attitudes of Language Learners}

Attitude is usually defined as a disposition or tendency to respond positively or negatively towards a certain thing such as an idea, object, person, or situation. Students have positive or negative attitudes towards the language they want to learn or the people who speak it. Gardner (1985) sees attitudes as components of motivation in language learning. He states that "motivation ... refers to the combination of effort plus desire to achieve the goal of learning the language plus favourable attitudes toward learning the language" (1985, p: 10). He also adds that the motivation to learn a foreign language is determined by basic predispositions and personality characteristics such as the learner's attitudes towards foreign people in general, and the target group and language in particular, motives for learning, and generalized attitudes. Wenden (1991) sees attitudes as including three components as the tendency to have a cognitive component, an evaluative component and a behavioural component. He emphasizes that certain attitudes tend to prompt learners to adopt particular learning behaviours. Starks and Paltridge (1996) submit a close relationship between learning a language and the attitudes towards the languages. Csizér and Dornyei (2005) also support the idea that attitude is an important factor in language learning on the internal structure of language learning motivation and its relationship with language choice and learning effort.

While comparing the attitudes of instructors and students towards distance learning, Hannay and Newvine, (2006) find that instructors have conflicting attitudes about distance education. Students may react differently to the online learning environment, depending 
on their skill levels and attitudes. To Inman, Kerwin and Mayes, (1999) while the instructors are willing to teach a distance learning class, they rate the courses as equal or lower in quality than traditional courses taught on campus. The students, on the other hand, are highly satisfied with these instructors and the distance courses taught. The students are not concerned about the interaction with the instructor. Drennan, Kennedy, and Pisarski (2005) find in a recent study that student satisfaction is influenced by positive perceptions toward technology and an autonomous learning mode. Clark (1993) states that the instructors who are prefer distance learning are those that are more familiar with the educational technology. Haas and Senjo (2004) indicated that while most held positive views towards the use of technology, far fewer are actually integrating technology-based methods of instruction into their courses.

Thompson (2005) investigated Chinese graduate students' experiences and attitudes on taking online courses in the USA. According to the results of the study, all participants indicate that online learning is an interesting experience for them but they have mixed attitudes toward this unfamiliar mode of learning. They emphasize that they enjoy easy resource sharing, easy record keeping and convenience of the discussion board the most. However, they are concerned about their writing skills in English, insufficient and deferred feedback and the lack of cultural exchange regarding online learning.

Much of the research about distance education favours it; however, in much of this research, only distance learning students are sampled. To achieve a more realistic picture of how students perceive distance education, it is important to question students who have participated in both traditional and distance education. This research will address this issue by comparing students' motivation and attitudes towards online distance learning and traditional in classroom education. In 2013, the in the university where the research is conducted, the University's Senate unanimously took a decision about teaching English as a foreign language through online courses by the instructors of the university. Since then students have been studying English through online courses provided by the university. English instruction is delivered by the lecturers of the School of Foreign Languages for three hours per week and at the end of the course students are expected to finish A1 level in reference to Common European Framework. Thus, the research questions of this study were formulated as follows:

$>$ To reveal motivational orientations and attitudes of EFL learners of online distance and traditional in-classroom instruction

$>$ Whether motivation and attitudes levels of learners from traditional in-class education and online distance education differ depending on age and gender

$>$ Whether EFL learners of online distance and traditional in-classroom instruction differ in terms of motivational orientations and attitudes towards learning English

\section{METHOD}

\section{Research Design}

Data for the study was collected during the 2014-2015 academic year. After the subjects had been informed verbally that their participation in the study was completely voluntary and would not influence their grade in the courses, they were informed about the study. The research design chosen for the study was a quantitative design. The correlation research method identifies relationship among variables.

\section{Study Group and its Characteristics}

As was mentioned above participants (may also be referred to as 'students' or 'learners') in this research comprised of $211(46.9 \%)$ females and $239(53.1 \%)$ males, totally 450 students. Of the students, $195(43.3 \%)$ studied English as a foreign language through traditional in classroom education whereas 255 of them (56.7\%) studied English through online distance education in the same university by the same instructors. The age of the participants ranged from 17 to 32 with the mean score of $21.1 \pm 2.1$. In the university where the research was conducted, randomly selected 500 students from different disciplines 
(including Faculty of Dentistry, Faculty of Pharmacy, Faculty of Education, Faculty of Arts and Sciences, Faculty of Fine Arts and Design, Faculty of Law, Faculty of Economics and Administrative Sciences, Faculty of Engineering, and Faculty of Medicine) were asked to participate in the study. The researchers explained the purpose of the study to the students and participation in the study was entirely voluntary. The questionnaires were given in the participants' mother language.

\section{Research Instruments}

The participants were asked to anonymously fill out a questionnaire involving three parts which respectively investigated their background information, attitudes and motivation of English as a foreign language. The first part of the questionnaire was a combination of open-ended and multiple-choice items concerning the participant's age, gender and whether they studied English in traditional classrooms or through online courses. The second part of the questionnaire was "The Scale of Attitude towards English" which aimed to investigate the participants' attitudes towards English. It was developed by Guven (2007) and was reported to have a Cronbach alpha of 0.75. The Scale itself contains 24 items, scored on a five point Likert scale, ranging from strongly agrees to strongly disagree. The scale involved 12 positively and 12 negatively worded items. The values of negatively worded items were reversed at data analysis stage. The third part of the questionnaire was taken from (AMTB) Attitude and Motivation Test Battery developed by Gardner (1985). In the Scale, only the foreign language "French" was replaced by "English". The scale covered 20 multiple-choice items with three options, investigating the motivational aspects of the subjects. The Motivation part of AMTB used in this study was comprised of two subscales: Motivational Intensity (MI) and Desire to Learn the Language (DLL).

\section{Validity and Reliability}

The Cronbach-alpha coefficient value for the overall reliability analysis of the "The Scale of Attitude towards English" for this study was found as 0.93. The Cronbach-alpha coefficient value for the reliability analysis of the "motivational intensity subscale" was found as $\mathbf{0 . 8 7}$ and for "desire to learn" subscale it was 0.89. All the Cronbach-alpha coefficient values show a satisfying level of reliability beyond the minimum desirable level of reliability as stated by Pallant (2005): "Ideally, the Cronbach alpha coefficient of a scale should be above 0.7".

\section{Data Analyses}

The data were analyzed through descriptive statistics (percentage, mean, median, and standard deviation) and t-tests and Pearson correlations. The level of significance was 0.05 for the analyses, which were conducted using SPSS.

\section{FINDINGS}

Motivational Orientations and Attitudes of EFL Learners of Online Distance and Traditional In-Classroom Instruction

Descriptive statistics were used to determine both groups' attitudes towards learning English. In table 1, mean scores of motivational construct and attitude for the learners of distance education and traditional in-class instruction can be seen. The questionnaire of attitudes towards learning English was a 5-likert scale survey with 5.00 as the highest score and $\mathbf{1 . 0 0}$ as the lowest score. According to the statistical results, the mean score of the first group (distance education) for attitudes towards English was $3.25 \pm 0.88$ while the mean score of the second group was $3.29 \pm 0.84$. So, it was found out that $108(42,4 \%)$ students 
had negative; $147(57,6 \%)$ had positive attitudes towards English from distance education group. Likewise, 75 (38.5 \%) students had negative; 120 (\%61.5) students had positive attitudes towards learning English as a foreign language from traditional in-class education group.

As for the motivation subscales; the highest score that could be obtained from each of the subscale was $\mathbf{3 0}$ while the lowest one was 10. Thus, when those scores are taken into account, for Motivational Intensity (MI) and Desire to Learn the Language (DLL) subscales, low level of motivation can be defined as a score between 10,0-16,6; moderate level between 16,7- 23,3; and high level between 23,4-30,0. The learners from Distance Education group had the mean scores of $3.10 \pm 0.89$ for motivational intensity and $3.50 \pm 0.94$ for desire to learn subscales while the other group - from traditional in-class education- had the mean scores of $1.70 \pm 0.53$ for motivational intensity and $1.90 \pm 0.50$ for desire to learn subscales.

Table: 1

Descriptive of Attitude and Motivation for EFL learners of Both Groups

\begin{tabular}{lllllll}
\hline VARIABLES & N & & MEAN & & SD & \\
\hline & Dist Ed & Trd Ed & Dist Ed & Trd Ed & Dist Ed & Trd Ed \\
Attitude & 213 & 156 & 3.25 & 3.29 & 0.88 & 0.84 \\
Motivational Intensity & 240 & 190 & 17.70 & 17.64 & 5.040 & 5.32 \\
Desire to Learn English & 226 & 192 & 18.73 & 19.07 & 5.055 & 5.04 \\
\hline
\end{tabular}

When the scores of the students are handled on the basis of the classification above, it is quite clear that 84 (33.7) students had low; 121 (48.6\%) students had moderate and 44 $(\mathbf{1 7 . 7 \% )}$ students had high scores in "Desire to Learn English" subscale whereas 110 (44.2\%) had low; 113 (45.4) had moderate and 26 (10.2) students had high scores in "Motivational Intensity" subscale in the distance education group. As for traditional in-class education group, 65 (33.9\%) students had low; 89 (46.4\%) students had moderate and 38 $(\mathbf{1 9 . 8 \% )}$ students had high scores in "Desire to Learn English" subscale whereas 89 $(46.8 \%)$ had low; 68 (35.8\%) had moderate and 33 (17.4\%) students had high scores in "Motivational Intensity" subscale in the traditional in-class education group. When the median scores of their motivational construct are considered, in general it can be said that both groups show similarities in their motivational construct and have moderately low level of motivational intensity and moderate level of desire to learn English as illustrated by Table 1.

Motivation and Attitudes Levels of Learners from Traditional In-Class Education and Online Distance Education Depending on Age and Gender

In order to look into male and female students' difference in their attitude-motivation levels, an independent-measures t test was applied to data. As can be seen in Table 2, the results indicated that gender was a significant factor in both attitude and motivation levels of the groups from online distance and traditional in-class education. The results interestingly revealed similarities in terms of attitude-motivation scores of male and female students. In both groups, male students had higher scores in their attitude and lower scores in their overall motivation scores. 
Table: 2

Mean Score, Standard Deviation and Range of Attitude-Motivation Scores in terms of Gender

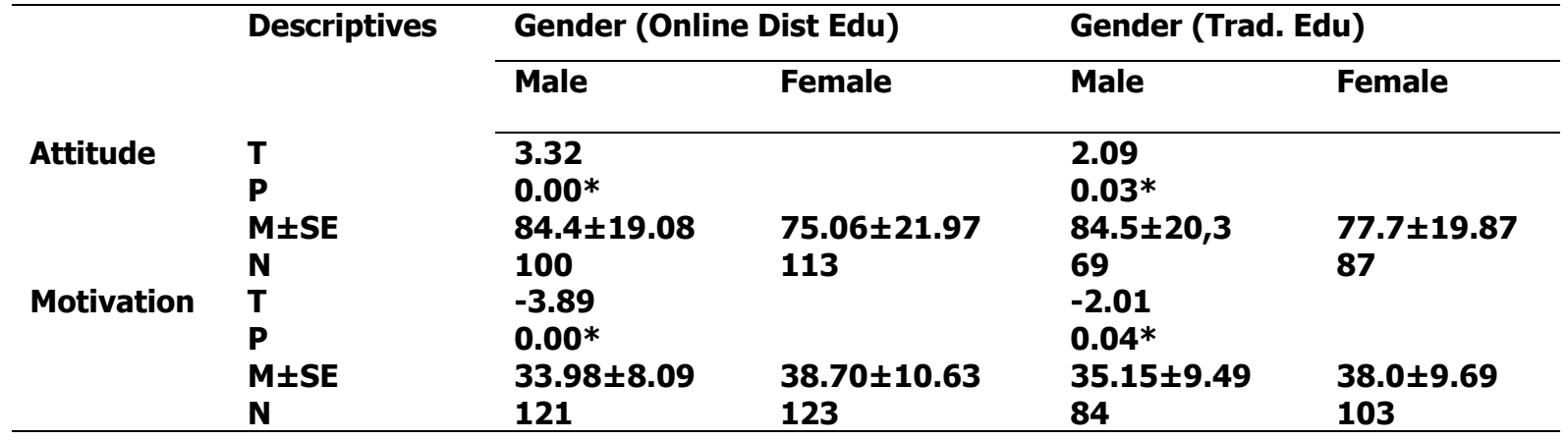

Regarding the effects of age on students' attitude and motivation towards learning English Pearson correlations were conducted and. Similar to the findings of gender, it was seen that age was not a significant factor in both groups suggesting that no relationship exists between age and attitude-motivation scores.

Table: 3

Pearson Correlations between Attitude-Motivation Scores of the learners and Age

\begin{tabular}{lllll} 
& \multicolumn{2}{l}{ Online Distance Education } & \multicolumn{2}{l}{ Traditional in-Class Education } \\
& $\mathbf{r}$ & $\mathbf{p}$ & $\mathbf{r}$ & $\mathbf{p}$ \\
\cline { 2 - 5 } Attitude & $-\mathbf{0 . 1 1 8}$ & $\mathbf{0 . 0 8 7}$ & -0.030 & 0.708 \\
Motivation & $\mathbf{0 . 1 5 6}$ & $\mathbf{0 . 0 1 5}$ & 0.089 & 0.224 \\
\hline
\end{tabular}

Comparison of motivational orientations and attitudes of EFL learners from online distance and traditional in-classroom education Students' attitude, motivational intensity and desire to learn English levels were compared in terms of the type of English education they are receiving as online distance and traditional in-class, by using an Independent Samples t-test and the results did not indicate statistically significant differences between them as can be seen in Table 4 .

Table: 4

Mean Score, Standard Deviation and Range of Attitude-Motivation Scores of the Groups

\begin{tabular}{|c|c|c|c|c|c|c|}
\hline & & $\mathbf{N}$ & Mean & $\begin{array}{l}\text { Std. } \\
\text { Dev }\end{array}$ & $\begin{array}{l}\text { t/F } \\
\text { Value* }\end{array}$ & $\mathbf{P}$ \\
\hline Attitude & $\begin{array}{l}\text { Online Distance Education } \\
\text { Traditional in-class Education }\end{array}$ & $\begin{array}{l}213 \\
156\end{array}$ & $\begin{array}{l}3.31 \\
3.36\end{array}$ & $\begin{array}{l}0.88 \\
0.84\end{array}$ & -0.58 & 0.56 \\
\hline $\begin{array}{l}\text { Motivational } \\
\text { Intensity }\end{array}$ & Online Distance Education & 249 & 1.87 & 0.50 & -0.70 & 0.48 \\
\hline \multirow{3}{*}{$\begin{array}{l}\text { Desire To Learn } \\
\text { English }\end{array}$} & Traditional in-class Education & 192 & 1.90 & 0.50 & & \\
\hline & Online Distance Education & 249 & 1.77 & 0.50 & -0.00 & 0.99 \\
\hline & Traditional in-class Education & 190 & 1.77 & 0.53 & & \\
\hline
\end{tabular}

\section{DISCUSSION AND CONCLUSIONS}

The results found in this study can be summarized in five topics: First, majority of the students from both groups have moderate level of motivation towards learning English. Second, students from both groups mostly have positive attitudes towards learning English. Third, gender is an important factor in both attitudes and motivation levels of EFL students in both groups. Males have more positive attitudes but less motivated than females in both 
groups. Forth, age is not an important factor in attitudes and motivation levels of EFL students from both groups. Lastly, there is not a significant factor between the motivation and attitudes of EFL students from on-line distance education and traditional in-class education.

To begin with, it must be stated here that the research yielded interesting results and the conclusions reached in the study were not preconceived by the researchers since the students of distance education and traditional in-class education seem to have substantial similarities in terms of their attitudinal and motivational features. Specifically, it seems that no matter how they study English (traditional or online distance) they show similar tendencies towards their English studies such as having low-moderate level of motivation and mostly positive attitudes towards learning English. One possible explanation of these findings is that it is clear from the results that the aforementioned advantages of distance education do not necessarily help learners enhance and disadvantages decrease the motivation of the learners towards English. Another possible explanation for this result is that the use of technology is not as encouraging as expected in changing the levels of students' motivation. This finding seems to be consistent with some previous studies (Dutton, 2002; Steven \& Switzer, 2006) that indicate online and on-campus students had the same level of motivation to complete a course.

The result that indicates the uniformity of motivation levels between the groups seems to confirm Gardner (1985), who stated that a highly motivated learner will want to learn the language, enjoy learning the language, and strive to learn the language in any place. Nevertheless, the motivation level of the students from both groups is not promising on behalf of language learning. In the Desire to Learn Language sub-dimension of the motivation scale, one third of the students have low, almost half of them have low moderate and only one fifth of them have high scores from both of the groups. In the subdimension of Motivational Intensity, there seems to be a slight difference between the groups. From distance education group, it was reported that almost half of the students have low or low moderate and very few students, only $10 \%$, have high levels of Motivational Intensity. From traditional in-class education it was seen that half of the students have low, one third of them have low moderate and almost one fifth of them have high levels of Motivational Intensity. Hence, it might be stated that students from both groups do not seem to be highly motivated to learn English. Moreover, as emphasized in the previous literature (Oxford et al., 1993; Chan et al., 1999) enhancing and maintaining students' motivation in distance education has a great importance on students' achievement (Ergul, 2004).

Contrary to this research, some previous studies indicated that motivation levels of students from distance education are higher than those of traditional in-class education (Rovai, et al. 2007; Hiltz, 1994). This contradiction may stem from the students' readiness for autonomy in language learning since distance education requires much more autonomy in foreign language learning process which is beyond the scope of this research. As stated by White (1994: 12-13), "distance learners must regulate and oversee the rate and direction of their learning to a much greater degree than classroom learners". However, the autonomous learning capacity of the students in the university where this research was conducted is in question. Additionally, some research

However, the number of the students who seem to have negative attitudes cannot be ignored. Even though more than half of the students from both groups have positive attitudes, more than one third of the students have negative attitudes towards learning English. Moreover, the number of students having negative attitudes from traditional inclass education group outnumbers the number of the students from distance education group. Considering the results of some previous studies reporting that language learners had positive attitudes towards the online language learning and were highly motivated (Hotho, 2000; Ushida, 2005, Cinkara and Bagceci, 2013), it can be concluded that distance education may have helped the learners of the present study to get more positive attitudes towards their English courses. The previous literature also indicates that negative 
attitudes, can impede language learning, since learners usually get those attitudes when they are not interested or have difficulties in their studies (Ellis, 1994). Those attitudes are usually expected to have a negative effect on learners. Above all, it should be kept in mind that students' attitudes can change. They may have negative attitudes at the beginning of learning process but as they realize the advantages of learning a language, with the help of instructors, their attitudes may change.

Within the present study, gender was found to be significant factor on students' motivation and attitudes towards learning English in both of the groups. Females seem to be more motivated than boys and have more positive attitudes towards learning English in the same way. It is clear that whether students are receiving English through online or face to face interaction does not affect their motivation levels and attitudes in terms of gender.

As a final point, the results indicated that distance education will be as good an alternative (if not better) than the physical classroom. Depending on the conclusions some implications can be noted. The low and low-moderate levels of motivation and negative attitudes of students towards foreign language courses found in the students of both groups (distance and traditional) in the present study have important implications for instructors in terms of course design. When attempting to design the courses, therefore, instructors should consider the importance of motivation and attitudes of the learners and look beyond the teaching methods, techniques, and materials that are currently being used. Since students from both groups look to need support to enhance their motivation and to get positive attitudes towards English, instructors had better help students to set goals for their language studies and control their feelings.

Further researches certainly need to be performed to suggest appropriate strategies that would help teachers to motivate their students, change negative attitudes of the students, and to train them as independent language learners that would facilitate students' language learning. Also, further researches should be considered to determine the reasons of low motivation students have.

Some limitations of the research can be noted. One important limitation of the study is that the participants of this study are students at a specific university in Turkey. Therefore, selection of the participants is naturally regionally and culturally biased. Moreover, the findings of the research may not be generalized to the entire population of language learners. The study was also restricted with investigating attitudes and motivations of the students from online and traditional in-class education, with gender and age as the only variable and did not account other aspects such as student's grades, academic achievements, proficiency, learning environment and autonomous learning capacity.

\section{BIODATA and CONTACT ADDRESSES of the AUTHORS}

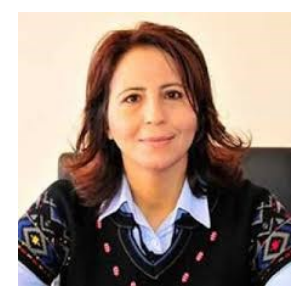

Dr. Gulten GENC is a lecturer at Inonu University, School of Foreign Languages, Malatya/Turkey. She received her MA degree in ELT department from Ataturk University and MA and PhD degrees in Educational Sciences from Inonu University. Her main interests are professional development of foreign language teachers, language learners' psychology, and using technology in foreign language teaching.

Dr. Gulten Genc

School of Foreign Languages, Inonu University, 44280, Malatya, TURKEY

GSM: 05334464053

e-Mail: gulten.genc@inonu.edu.tr 


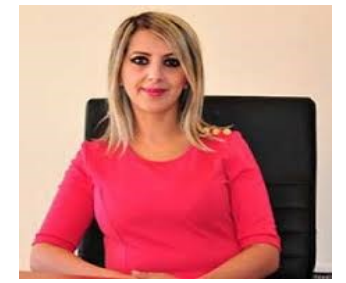

Emine KULUSAKLI is an English instructor at Inonu University, School of Foreign Languages, Malatya/Turkey. She received her MA degree in English Language and Literature department from Ataturk University and she is working on her PhD in Istanbul Aydin University right now. Her main interests are, discourse analysis, psycholinguistics, and sociolinguistics.

\section{Emine KULUSAKLI}

School of Foreign Languages, Inonu University, 44280, Malatya, TURKEY

GSM: 05325828917

e-Mail: emine.kulusakli@inonu.edu.tr

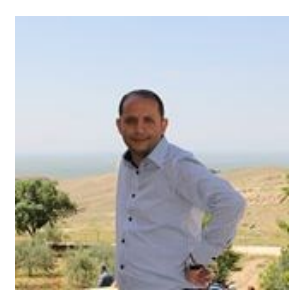

Savas AYDIN is an English instructor at Inonu University, School of Foreign Languages, Malatya/Turkey. He received her MA degree in ELT department from Ondokuz Mayis University and MA degree in Educational Sciences from Inonu University. He is working on his PhD in Inonu University right now. His main interests are educational administration, classroom management, and professional development.

\section{Savas AYDIN}

School of Foreign Languages, Inonu University, 44280, Malatya, TURKEY

GSM: 05322051486

E-mail: savas.aydin@inonu.edu.tr

\section{REFERENCES}

Allen, M., Mabry, E., Mattrey, M., Bourhis, J., Titsworth, S. and Burrell, N. (2004), Evaluating the Effectiveness of Distance Learning: A Comparison Using MetaAnalysis. Journal of Communication, 54 (402-420). DOI: 10.1111/j.1460-2466. 2004. tb02636.x

Bisciglia, M., Monk-Turner, E. (2002). Differences in attitudes between on-site and distance-site students in group teleconference courses. The American Journal of Distance Education, $16(1)$, 37-52.

Chan, M. S. C., Jegede, O., Fan, R. Y. K., Taplin, M. and Yum, J. C. K. (1999). A comparison of the study habits and preferences of high achieving and low achieving Open University students. In Ding Xingfu (Ed.) Proceedings of the 13th Annual Conference of the Asian Association of Open Universities, Beijing. 2(1-16).

Cinkara, E., Bagceci, B. (2013). Learners' attitudes towards online language learning and corresponding success rates. Turkish Online Journal of Distance Education-TOJD, 14(2), 118-129

Clark, T. (1993). Attitudes of higher education faculty toward distance education: a national survey. The American Journal of Distance Education, 7, 19-33.

Coussement, S. (1995). Educational telecommunication: Does it work? An attitude study. (ERIC Document Reproduction Service No. ED391465) 
Csizer, K., Dornyei, Z. (2005) The internal structure of language learning motivation and its relationship with language choice and learning effort, The Modern Language Journal, 89, 19-36.

Dornyei, Z. (1990). Analysis of motivation components in foreign language learning. In 9th World Congress of Applied Linguistics, Thessaloniki, Greece, April (p1521).Retrieved on June, 2015 and from: http//files.eric.ed.gov/fulltext/ED323810.pdf

Drennan, J., Kennedy, J., \& Pisarksi, A. (2005). Factors affecting student attitudes toward flexible online learning in management education. The Journal of Educational Research, 98(6), 331-340.

Dutton, J., Dutton, M., Perry, J. (2002). How do online students differ from lecture students? Journal of Asynchronous Learning Networks, 6(1). Retrieved on August 2015 from www.sloan-c.org/publications/jaln/v6n1/v6n1_dutton.asp

Egan, M., Gibb, G. (1997). Student-centered instruction for the design of telecourses. In T. Cyrs (Ed.), Teaching and learning at a distance: What it takes to effectively design, deliver, and evaluate programs (33-39). San Francisco, CA: Jossey-Bass.

Ellis, R. (1994). The Study of Second Language Acquisition. Oxford: Oxford University Press.

Ergul, H. (2004). Relationship between student characteristics and academic achievement in distance education and application on students of Anadolu University. Turkish Online Journal of Distance Education-TOJDE 5(2), 81-90

Fjortoft, N. F. (1996). Persistence in a distance learning program: A case in pharmaceutical education. American Journal of Distance Education, 10(3), 49-59.

Gardner, R.C. (1985) Social Psychology and Second Language Learning: The Role of Atttitude and Motivation. London: Edward Arnold.

Garrison, D. R., Shale, D. (1987). Mapping the boundaries of distance education: Problems in defining the field. American Journal of Distance Education, 1(1), 7 - 13.

Greenberg, G. (1998). Distance education technologies: Best practices for K-12 settings. IEEE Technology and Society Magazine, (Winter) 36-40.

Guven, Z. Z. (2007). Öğrenme stillerine dayalı etkinliklerin öğrencilerin dinleme becerisi erişileri, İngilizce dersine yönelik tutumları ve öğrenilenlerin kalıcılığına etkisi. Yayımlanmamış doktora tezi, Selçuk Üniversitesi Sosyal Bilimler Enstitüsü, Konya.

Hannay, M., Newvine, T. (2006). Perceptions of distance learning: A comparison of online and traditional learning. Journal of Online Learning and Teaching, 2(1), 1-11.

Hardy, D. W., Boaz, M. H. (1997). Learner development: Beyond the technology. In T. E. Cyrs (Eds.), Teaching and learning at a distance: What it takes to effectively design, deliver, and evaluate programs (pp.41-48). San Francisco: Jossey-Bass.

Haas, S. M., Senjo, S.R. (2004). Perceptions of effectiveness and the actual use of technology-based methods of instruction: a study of California criminal justice and crime-related faculty. Journal of Criminal Justice Education, 15, 2, 263-285.

Hiltz, S. R. (1994). The virtual classroom: Learning without limits via computer networks. Norwood, NJ: Ablex. 
Hotho, S. (2000). "Same" or "different"? A comparative examination of classroom factors in second Language settings. Foreign Language Annals, 320 - 329.

Imel, S. (1998). Myths and realities of distance learning. Columbus, Ohio: ERIC Clearinghouse on Adult, Career, and Vocational Education. Ohio State University. (Eric Document Reproduction Service No. ED 414 446).

Inman, E., Kerwin, M., Mayes, L. (1999). Instructor and student attitudes toward distance learning. Community College Journal of Research and Practice: 23 (6), 581-592.

Keegan, D. (1986). The foundations of distance education. London: Croom Helm.

Keegan, D. (1995). Distance education technology for the new millennium: compressed video teaching. ZIFF Papiere. Hagen, Germany: Institute for Research into Distance Education. (Eric Document Reproduction Service No. ED 389 931).

Klesius, J. P., Homan, S. P., \& Thompson, T. (1997). Distance education compared to traditional instruction: The students' view. International Journal of Instructional Media, 24(3), 207-227.

Moore, D.R., Lockee, B.B. (1998). A taxonomy of bandwidth: considerations and principles to guide practice in the design and delivery of distance education. Unpublished manuscript: Portland State University.

Moore, M. G., and Thompson, M. M. (1997). The effects of distance education (Rev. ed.). ACSDE Research Monograph, 15. The Pennsylvania State University, PA. American Center for the Study of Distance Education.

Ortega, L. (2009). Understanding second language acquisition. London: Hodder Education.

Oxford, Re., Park-Oh, Y., Ito, S., Sumrall, M. (1993). Factors affecting achievement in a satellite-delivered Japanese language program. The American Journal of Distance Education. 7(1).

Pallant, J., (2005). SPSS survival manual: a step by step guide to data analysis using SPSS for windows (Version 12). 2nd ed. Maidenhead: Open University Press.

Perraton, H. (1988). A theory for distance education. In D. Sewart, D. Keegan and B. Holmberg (Eds.) Distance Education: International Perspectives (34-45). New York: Routledge.

Rovai, A., Ponton, M., Wighting, M., Baker, J. (2007). A comparative analysis of student motivation in traditional classroom and e-learning courses. International Journal on E-Learning, 6(3), 413-432.

Sherry, L. (1996). Issues in Distance education. International Journal of Educational Telecommunications, 1(4), $337-365$.

Spooner, F., Jordan, L., Algozzine, B., Spooner, M. (1999). Student ratings of instruction in distance education and on-campus classes. The Journal of Educational Research 92(3), $132-140$.

Starks, D., Paltridge, B. (1996) A note on using sociolinguistic methods to study nonnative attitudes towards English, World Englishes, 15(2), 217-224. 
Stevens, T., Switzer, C. (2006). Online and Traditional Student Differences: Differences between online and traditional students: A study of motivational orientation, self-efficacy, and attitudes. Turkish Online Journal of Distance Education-TOJDE. T2) 1302-6488

Teaster, P., Blieszner, R. (1999). Promises and pitfalls of the interactive television approach to teaching adult development and aging. Educational Gerontology, $25(8), 741-754$.

Thompson, L., Ku, H.-Y. (2005) Chinese graduate students' experiences and attitudes towards online learning. Educational Media International. 42 (1), 33-47

Ushida, E. (2005). The role of students' attitudes and motivation in second language learning in online language courses. CALICO Journal, 49-78.

VanPatten, B., Benati, A. G. (2010). Key terms in second language acquisition. London: Continuum International Publishing Group.

Wheatley, B., Greer, E. (1995). Interactive television: a new delivery system for a traditional reading course. Journal of Technology and Teacher Education 3 (4), 343-350.

White, C. (1994) Language learning strategy research in distance education: The yoked subject technique. Research in Distance Education 3, 10-20. 